\title{
$\alpha$-Syn Suppression Reverses Synaptic and Memory Defects in a Mouse Model of Dementia with Lewy Bodies
}

\author{
Youngshin Lim, Victoria M. Kehm, Edward B. Lee, James H. Soper, Chi Li, John Q. Trojanowski, and Virginia M.-Y. Lee \\ Department of Pathology and Laboratory Medicine, Institute on Aging and Center for Neurodegenerative Disease Research, University of Pennsylvania \\ School of Medicine, Philadelphia, Pennsylvania 19104
}

\begin{abstract}
Abnormally accumulated $\alpha$-synuclein ( $\alpha$-syn) is a pathological hallmark of Lewy body-related disorders such as Parkinson's disease (PD) and dementia with Lewy body disease (DLB). However, it is not well understood whether and how abnormal accumulation of $\alpha$-syn leads to cognitive impairment or dementia in PD and DLB. Furthermore, it is not known whether targeted removal of $\alpha$-syn pathology can reverse cognitive decline. Here, we found that the distribution of $\alpha$-syn pathology in an inducible $\alpha$-syn transgenic mouse model recapitulates that in human DLB. Abnormal accumulation of $\alpha$-syn in the limbic system, particularly in the hippocampus, correlated with memory impairment and led to structural synaptic deficits. Furthermore, when $\alpha$-syn expression was suppressed, we observed partial clearing of pre-existing $\alpha$-syn pathology and reversal of structural synaptic defects, resulting in an improvement in memory function.
\end{abstract}

\section{Introduction}

Cognitive dysfunction is common in Lewy body disorders, including dementia with Lewy bodies (DLB) and Parkinson's disease (PD). DLB accounts for $\sim 30 \%$ of all age-related dementias, and up to $40 \%$ of Alzheimer's disease cases exhibit $\alpha$-synuclein ( $\alpha$-syn) pathology (Parkkinen et al., 2003; Jellinger, 2004; Mikolaenko et al., 2005; Zaccai et al., 2005). Of PD patients, $20-40 \%$ have cognitive impairments at disease onset, and $\sim 80 \%$ of PD patients eventually develop dementia (PDD) (Aarsland et al., 2008). Little attention has been given to mechanisms underlying the cognitive and psychiatric symptoms associated with PDD and DLB.

Abnormal $\alpha$-syn is key to the pathogenesis of Lewy body disorders. In idiopathic PD, PDD, and DLB, pathologic accumulations of $\alpha$-syn in Lewy bodies (LBs) are observed in cell bodies as well as in neuronal processes and synapses as Lewy neurites (Spillantini et al., 1997; Kramer and Schulz-Schaeffer, 2007). $\alpha$-Syn inclusions are also seen in familial PD linked to point mutations within or duplications/triplications of $\alpha$-syn (SNCA) gene (Duda et al., 2002b; Ikeuchi et al., 2008; Seidel et al., 2010). Furthermore, recent genome-wide association studies identified SNCA as a common risk factor for PD (Satake et al., 2009; SimónSánchez et al., 2009). Together, these observations suggest a caus-

Received Feb. 3, 2011; revised April 26, 2011; accepted May 18, 2011.

Author contributions:Y.L. and V.M.-Y.L. designed research; Y.L., V.M.K., J.H.S., and C.L. performed research; Y.L.,

E.B.L., J.Q.T., and V.M.-Y.L. analyzed data; Y.L., E.B.L., J.Q.T., and V.M.-Y.L. wrote the paper.

The authors declare no competing financial interests.

This work was supported by National Institutes of Health Grants NS053488 and AG10124, and by the Picower Foundation. We thank Dr. T. Abel for the CaMKIl $\alpha$-tTA mouse strain and Dr. D. Borchelt for the PrPtetP plasmid. We are grateful to Michiyo Iba for technical help on behavioral tests and Michael Partain for immunostaining of DLB cases.

Correspondence should be addressed to Dr. Virginia M.-Y. Lee, Center for Neurodegenerative Disease Research, Department of Pathology and Laboratory Medicine, 3rd Floor Maloney Building, 3600 Spruce Street, Philadelphia, PA 19104-4283. E-mail:vmylee@upenn.edu.

DOI:10.1523/JNEUROSCI.0618-11.2011

Copyright $\odot 2011$ the authors $\quad 0270-6474 / 11 / 3110076-12 \$ 15.00 / 0$ ative role for $\alpha$-syn in sporadic and inherited forms of PD. However, it is not clear how $\alpha$-syn leads to neurodegeneration, and in particular how $\alpha$-syn dysfunction leads to dementia.

Studies in cultured neurons have shown that increased $\alpha$-syn expression in the absence of $\alpha$-syn inclusions causes synaptic dysfunction, including defects in neurotransmitter release, synaptic vesicle recycling or endocytosis/exocytosis, and synaptic protein levels (Nemani et al., 2010; Scott et al., 2010). These observations suggest that synaptic dysfunction induced by $\alpha$-syn may be the substrate for cognitive dysfunction and neurodegeneration. Whether $\alpha$-syn pathology is associated with similar synaptic dysfunction before overt neurodegeneration, and whether this correlates with cognitive dysfunction have not been determined in vivo.

Tetracycline-controllable transgenic ( $\mathrm{tg}$ ) mice have facilitated studies of pathogenesis and therapeutics of several neurodegenerative diseases (Tremblay et al., 1998; Jankowsky et al., 2005; Santacruz et al., 2005; Nuber et al., 2008; Lim et al., 2010). It is not known whether suppression of $\alpha$-syn expression can arrest or even revert $\alpha$-syn pathology and associated behavioral deficits. Here, we studied mutant (A53T) and wild-type (WT) $\alpha$-syn tg models of PDD/DLB using a tet-off system and the CaMKII $\alpha$ promoter to explore the consequences of reversible $\alpha$-syn expression in aged mice. Abnormal accumulation of $\alpha$-syn was detected in multiple forebrain regions, particularly in limbic regions, with a distribution highly similar to that observed in DLB (McKeith et al., 2005). These tg mice also showed age-dependent changes in synaptic structure and memory impairments. Furthermore, suppression of $\alpha$-syn expression in old mice (1) cleared a significant amount of $\alpha$-syn pathology in the hippocampus and arrested its progression in other areas, (2) reverted hippocampal synaptic defects, and (3) improved memory function. Our data suggest that $\alpha$-syn overexpression and accumulation can cause synaptic dysfunction and memory impairment before overt neuronal loss, and that these abnormalities can be reversed by suppressing $\alpha$-syn transgene expression. 


\section{Materials and Methods}

Transgenic mice. As described previously (Lim et al., 2010), a tg activator line on the C57BL/6J background expressing tetracycline-controlled transactivator (tTA) under the control of CaMKII $\alpha$ promoter (CaMKII $\alpha$-tTA) (Mayford et al., 1996) was crossed to $\alpha$-syn responder lines in B6C3H F2 background [tetP-WT $\alpha$-syn (line 7) and tetP-A53T $\alpha$ syn (line 33); these lines were maintained by crossing to $\mathrm{B} 6 \mathrm{C} 3 \mathrm{H}$ F1 wildtype mice purchased from Jackson Laboratories], and the offspring were used for experimental analysis. The four F1 genotypes are abbreviated as follows: nTg (CaMKII $\alpha-t T A^{-/-}$; tetP- $\alpha$-syn $\left.{ }^{-\prime-}\right), \alpha$-syn (CaMKII $\alpha-$ $t \mathrm{TA}^{-/-} ;$tetP- $\left.\alpha-\mathrm{syn}^{+/-}\right)$, tTA (CaMKII $\alpha-\mathrm{tTA}^{+/-} ;$tetP- $\left.\alpha-\mathrm{syn}^{-/-}\right)$, and tTA/ $\alpha$-syn $\left(\right.$ CaMKII $\alpha-t \mathrm{TA}^{+/-}$; tetP- $\alpha$-syn $\left.{ }^{+/-}\right) ; \alpha$-syn refers to both $\mathrm{WT} \alpha$-syn or A53T $\alpha$-syn if not otherwise specified. To bypass the postnatal developmental defects described previously in these bigenic mice (Lim et al., 2010), mice in this study were fed a doxycycline (dox) diet ( $200 \mathrm{mg} / \mathrm{kg}$ of dox) to suppress transgene expression from the observed date of insemination (E0.5) until postnatal day 21 (P21) unless otherwise stated. All housing and breeding of the animals were performed in accordance with the NIH Guide for the Care and Use of Experimental Animals and approved by the University of Pennsylvania Institutional Animal Care and Use Committee.

Brain tissue collection. Mice were lethally anesthetized as described previously (Lim et al., 2010) and perfused with PBS. The brains were dissected, weighed, and cut sagittally into two hemispheres. One hemisphere was fixed overnight in 10\% neutralized-buffered formalin (NBF; Fisher Scientific) or $70 \%$ ethanol/150 mM NaCl for immunohistochemistry, and the other hemisphere was further dissected into olfactory bulb, cerebral cortex, hippocampus, subcortical areas (including the basal ganglia, thalamus, hypothalamus, and related structures), mammillary body, cerebellum, and brainstem, and then immediately frozen on dry ice and kept at $-80^{\circ} \mathrm{C}$ for biochemical analysis.

Immunohistochemistry, immunofluorescence, and histological staining. Immunohistochemistry and immunofluorescence staining on paraffin sections were conducted as described previously (Lim et al., 2010). To detect $\alpha$-syn, the previously described mouse monoclonal antibodies (MAb), Syn 303 (1:7000), LB509 (1:2000), and P-syn/81A (1:10,000) (Baba et al., 1998; Duda et al., 2002a; Waxman and Giasson, 2008), as well as newly generated Syn 1150 were used. Syn 1150 is an affinity-purified rabbit polyclonal Ab raised against the peptide DMPVDPDNEAYEMPSC corresponding to nonphosphorylated amino acids $115-129$ of $\alpha$-syn and affinity excluded against the peptide DMPVDPDNEAFAAFAC such that the antibody only recognized amino acid residues $125-129$ of $\alpha$-syn. This strategy enabled us to obtain a polyclonal antibody to nonphosphorylated $\alpha$-syn to complement 81A, which is specific for phospho-Ser129. Other MAbs used in this study were anti-NeuN (Millipore, 1:1000), anti-Synaptophysin (Millipore, 1:200), anti-Synaptotagmin (Synaptic Systems, 1:1000), anti-SNAP25 (Santa Cruz Biotechnology, 1:2000), anti-Syntaxin (Sigma-Aldrich, 1:5000), and anti-Synaptobrevin 2 (Synaptic Systems, 1:2000); rabbit polyclonal Abs were anti-GFAP (DAKO, 1:10,000), anti-CSP $\alpha$ (Synaptic Systems, 1:1000), and anti-Synapsin I (Invitrogen, 1:200). For NBF-fixed tissues, antigen retrieval was performed by heating the sections at $99^{\circ} \mathrm{C}$ in $0.01 \mathrm{M}$ citric acid for $10 \mathrm{~min}$ as described previously (Lim et al., 2010). Standard protocols were used for hematoxylin and eosin (H\&E) staining and ThioS staining. Images of stained sections were captured with Olympus DP software using Olympus DP71 camera attached to an Olympus BX51 microscope.

Sequential extraction of brains with buffer of increasing strength. Cortex and hippocampus tissue from nTg and tTA/A53T $\alpha$-syn mice were dissected at progressive stages of disease (see Fig. 4). Sequential extraction of these dissected tissues was performed as described previously (Giasson et al., 2002) with slight modification. High salt buffer (HS) was used at 6 $\mathrm{ml} / \mathrm{g}, 1 \%$ Triton in HS buffer (HS/T) at $6 \mathrm{ml} / \mathrm{g}$, RIPA at $4 \mathrm{ml} / \mathrm{g}$, and either formic acid (FA) or $2 \%$ SDS at $2 \mathrm{ml} / \mathrm{g}$. For immunoblotting, $15 \mu \mathrm{g}$ of proteins from HS, HS/T, RIPA, and 2\% SDS samples and $5 \mu \mathrm{l}$ of FA samples were loaded on $15 \%$ polyacrylamide gels and probed with LB 509 (specific for human $\alpha$-syn, 1:2000).

Pathology grading. For $\alpha$-syn pathology grading, immunohistochemistry using $\alpha$-syn antibody (Syn 303) was performed on paraffin- embedded coronal sections of the mouse brain fixed with 70\% ethanol/ $150 \mathrm{~mm} \mathrm{NaCl}$. $\alpha$-Syn pathology was graded in 13 selected areas of the brain with numeric values ranging from 0 (absent) to 3 (severe) with 0.5 increments. The 13 selected areas included olfactory bulb, septum, cortex, hippocampus, dentate gyrus, subthalamic nucleus, mammillary body, thalamus, hypothalamus, dorsal midbrain, ventral midbrain, brainstem, and spinal cord. For each area, $8-10$ sections were manually examined per each mouse to assign the pathology score.

Behavioral studies. Animals were randomized and the experimenter was blinded to genotype for the duration of behavioral testing. Mice used in the behavioral test were $\mathrm{nTg}, \alpha$-syn, tTA, and tTA/ $\alpha$-syn, and the ages of mice were 4 months (females), 8 months (females), 12 months (males), and 12 months ${ }^{\text {dox9-12m }}$ (males) with a cross-sectional design ( $n=8-13$ for each genotype per age). To suppress $\alpha$-syn expression, tg mice (12 months ${ }^{\text {dox9-12m }}$ ) mice were fed with dox diet between $9-12$ months of age in addition to the developmental period (E0.5-P21). Contextual and cued fear-conditioning tests were performed in chambers as described previously (Zhang et al., 2005). Mice were handled for $3 \mathrm{~min}$ $1 \mathrm{~d}$ before the training day. Test subjects were placed into the conditioning chamber and allowed to explore for $2 \mathrm{~min}$. Conditioning consisted of a single pairing of an auditory cue $(2800 \mathrm{~Hz}, 85 \mathrm{~dB})$ with a footshock $(1.5$ $\mathrm{mA}$ scrambled). The auditory cue was introduced $2 \mathrm{~min}$ after the training session started and was $30 \mathrm{~s}$ in duration. The footshock was delivered continuously during the last $2 \mathrm{~s}$ of the auditory cue. The subject was removed from the chamber $3 \mathrm{~min}$ later and returned to its home cage. Twenty-four hours later, each subject mouse was placed in the test chamber and monitored for $5 \mathrm{~min}$ to test for contextual fear (freezing score for 3 min was used to calculate percentage freezing). Two hours later, the context was altered, and each mouse was placed in the altered chamber and allowed $3 \mathrm{~min}$ for exploration, after which the auditory tone cue of 3 min was delivered to test for cued fear. Freezing behavior (complete absence of movement except for respiration and heart beat) was sampled at $5 \mathrm{~s}$ intervals during conditioning as well as testing, and the percentage of those intervals in which the mouse exhibited freezing behavior was calculated.

Statistical analysis. Statistical analyses of the behavioral tests were performed by one-way ANOVA with Tukey's multiple comparison post hoc analysis.

\section{Results}

\section{Abnormal accumulation of $\alpha$-syn in limbic areas and late onset neurodegeneration in cortex and hippocampus}

We used previously generated mutant A53T and WT $\alpha$-syn tg mice with a tet-off system and the CaMKII $\alpha$ promoter (tTA/ $\alpha$ syn) to model human DLB (Lim et al., 2010). We performed neuropathologic analysis of multiple lines of adult tTA/ $\alpha$-syn mice and age-matched littermate controls (nTg, $\alpha$-syn, or tTA monogenic; see Materials and Methods for cross breeding). These mice express human WT $\alpha$-syn (line 7) or the familial PDlinked A53T mutant $\alpha$-syn (line 33) mainly in forebrain neurons (Lim et al., 2010). To suppress developmental defects caused by $\alpha$-syn expression during gestation as previously reported (Lim et al., 2010), all mice were maintained on a dox diet $(200 \mathrm{mg} / \mathrm{kg})$ through development from E0.5 until P21 to inhibit transgene expression; mice were then switched to a regular diet to induce transgene expression.

To examine whether the tTA/A53T $\alpha$-syn mice show PDD/ DLB-like $\alpha$-syn neuropathology, we analyzed $\alpha$-syn immunohistochemistry for the presence of $\alpha$-syn pathology. No abnormal $\alpha$-syn immunoreactive aggregates were observed before 4 months. At 4 months of age (the actual age of the mice regardless of the onset of the tg $\alpha$-syn expression), abnormal $\alpha$-syn staining was detected mainly in the limbic areas, including the cingulate cortex, hippocampus, dentate gyrus, and mammillary body. At 8 months, the distribution of $\alpha$-syn was similar, but the amount of 


\section{A}

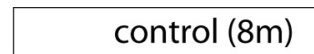

tTA/A53T $\alpha-\operatorname{syn}(4 \mathrm{~m})$

tTA/A53T $\alpha$-syn (8m)

B \begin{tabular}{r|}
\hline Human DLB \\
\hline Syn 303
\end{tabular}
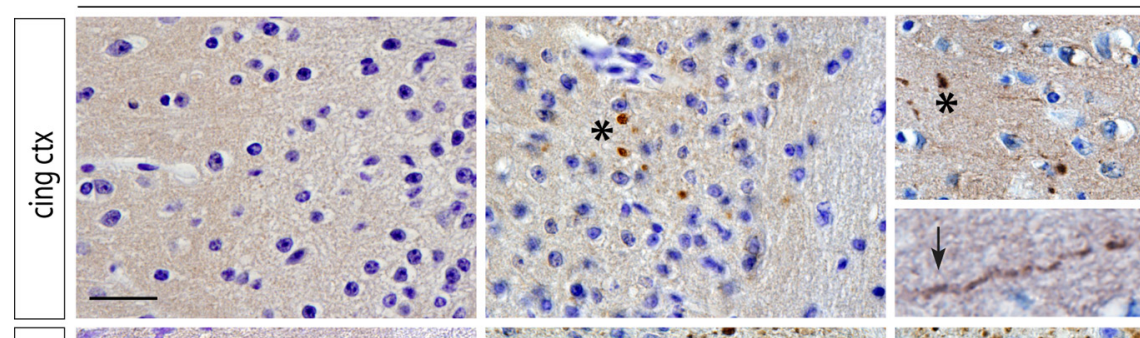

Syn 303
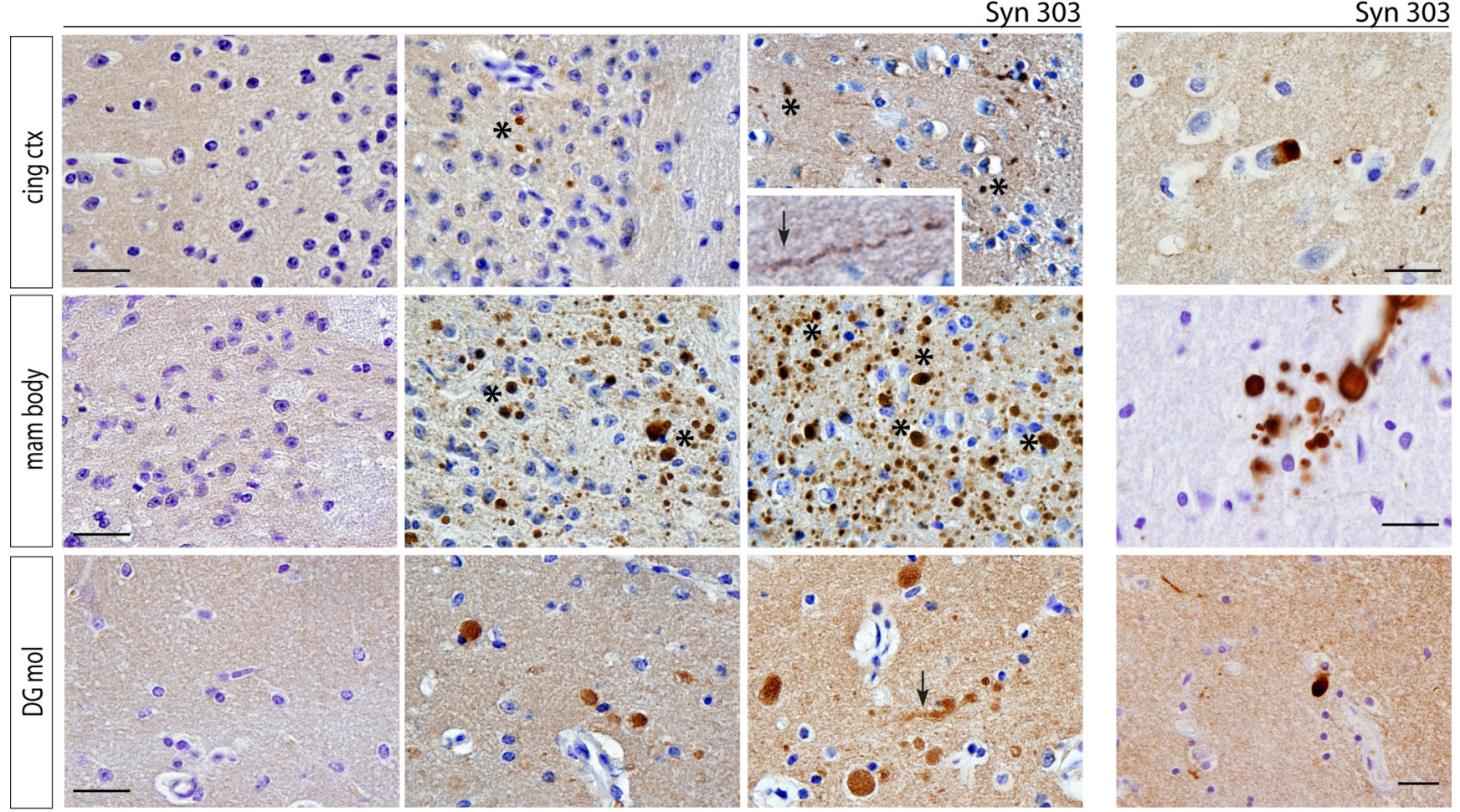

Syn 1150
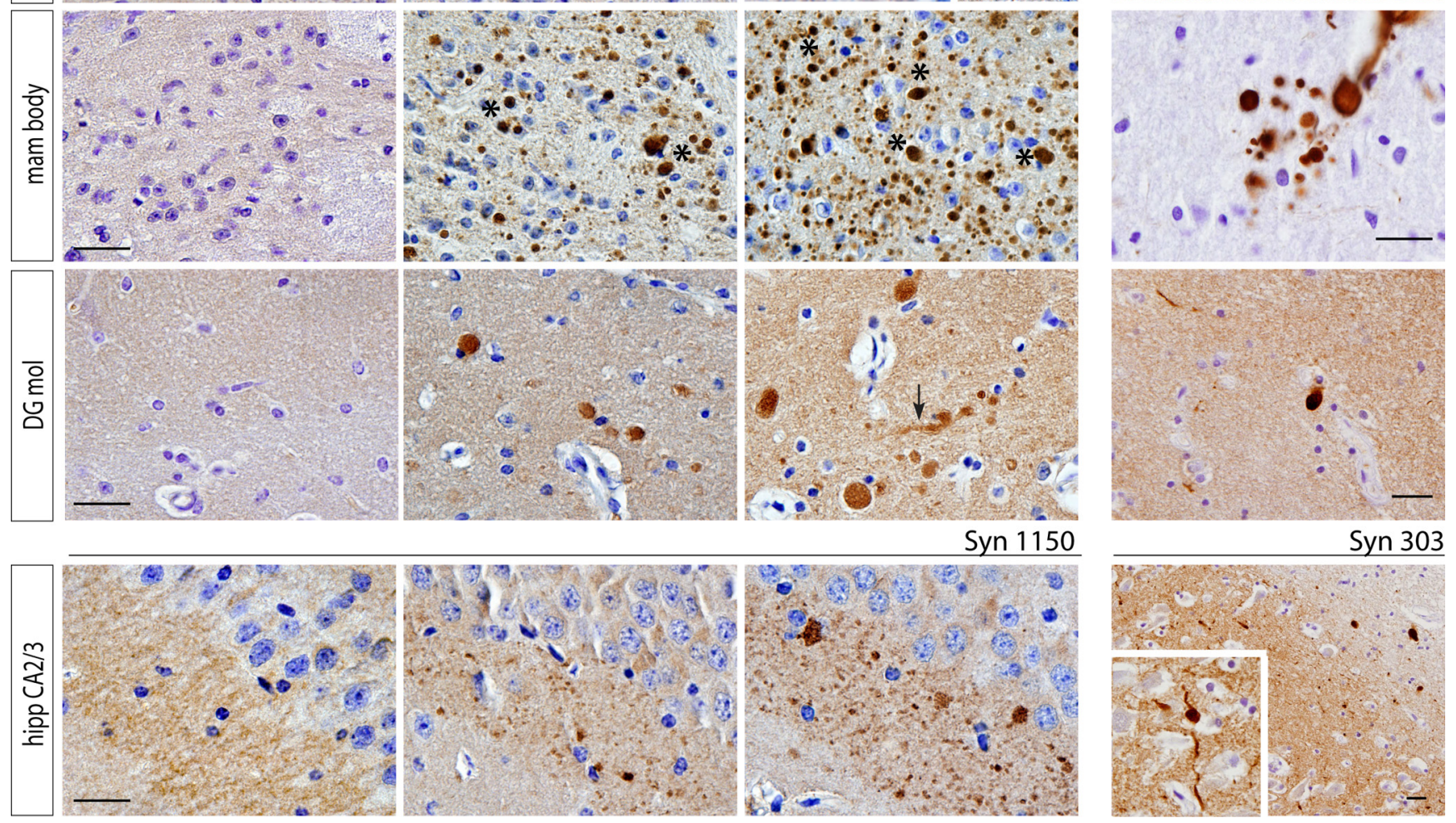

Syn 303

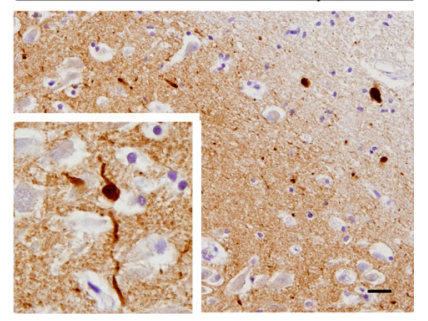

Figure 1. Progressive $\alpha$-syn pathology in the limbic areas. Paraffin sections of the cingulate cortex (cing ctx), mammillary body (mam body), molecular layer of the dentate gyrus (DG mol), and hippocampal CA2/3 (hipp CA2/3) areas from the control (A53T $\alpha$-syn monogenic) and tTA/A53T $\alpha$-syn bigenic mice ( $n=6-8$ mice per group) $(\boldsymbol{A})$ and from human DLB patients $(n=4)$ ( $\boldsymbol{B})$ were stained with anti-syn antibodies, Syn 303 or Syn 1150 (brown), and counterstained with hematoxylin (blue). Hereafter, all the counterstaining is done with hematoxylin unless stated otherwise. Insets in $\boldsymbol{A}$ and $\boldsymbol{B}$ indicate enlarged images of another area with neuritic pathology. Note that most of the accumulated $\alpha$-syn in the mice shows a dot-like pattern (asterisks), and some shows a neuritic pattern (arrows) at these ages. Scale bars, $20 \mu \mathrm{m}$.

$\alpha$-syn pathology was more pronounced (Fig. 1A). Although $\alpha$-syn inclusions in the cingulate cortex and hippocampus are well documented in human PDD/DLB cases (Fig. 1B) (McKeith et al., 2005), $\alpha$-syn pathology in the mammillary body has not been commonly reported. Therefore, we examined mammillary bodies of the PDD/DLB cases and confirmed that $\alpha$-syn pathology was present in human postmortem PDD/DLB brains (Fig. $1 B$ ). At these stages ( 4 and 8 months), affected regions showed a dot-like granular pattern of abnormal $\alpha$-syn accumulation with virtually no perikaryal inclusions consistent with a synaptic or neuritic localization (Fig. 1A). This dot-like granular pattern of abnormal $\alpha$-syn accumulation was also detected in another A53T $\alpha$-syn line (line 9), suggesting that $\alpha$-syn pathology is a specific result of the A53T $\alpha$-syn mutation. The olfactory bulb, septum, and subthalamic nucleus also showed abnormal $\alpha$-syn immunoreactivity at 4 months, which increased at 8 months (data not shown), but neocortical pathology was limited or absent at both ages (data not shown). We also observed limited $\alpha$-syn pathology in the superior colliculus, ventral tegmental area, brainstem, and spinal cord, although the amount of pathol- ogy in these areas was very low and did not progress after 8 months of age (data not shown). We postulate that dot-like $\alpha$-syn pathology in the brainstem and spinal cord may represent neuritic pathology in the neural projections from the forebrain, or alternatively that there may be some leakiness in the control of transgene expression. Together, we found that the distribution of $\alpha$-syn pathology in these mice is very similar to the limbicpredominant pattern of $\alpha$-syn pathology of human DLB or PDD patients (data not shown) (Fig. $1 A, B$ ).

In contrast, older (20-22 month) tTA/A53T $\alpha$-syn mice showed cytoplasmic accumulation of $\alpha$-syn in a wide distribution, detected throughout the neocortex and hippocampus as well as the cingulate and entorhinal cortex (Fig. 2A). We also observed severe neuronal loss involving both the cortex and hippocampus (Fig. $2 B$ ). H\&E staining and NeuN immunohistochemistry showed severe reduction in cortex thickness and cortical neuron numbers, as well as severe loss of hippocampal pyramidal cells and dentate gyrus granule cells (Fig. 2C). Subcortical areas such as the thalamus and hypothalamus, cerebellum, brainstem, and spinal cord were spared compared with the cortex 
A
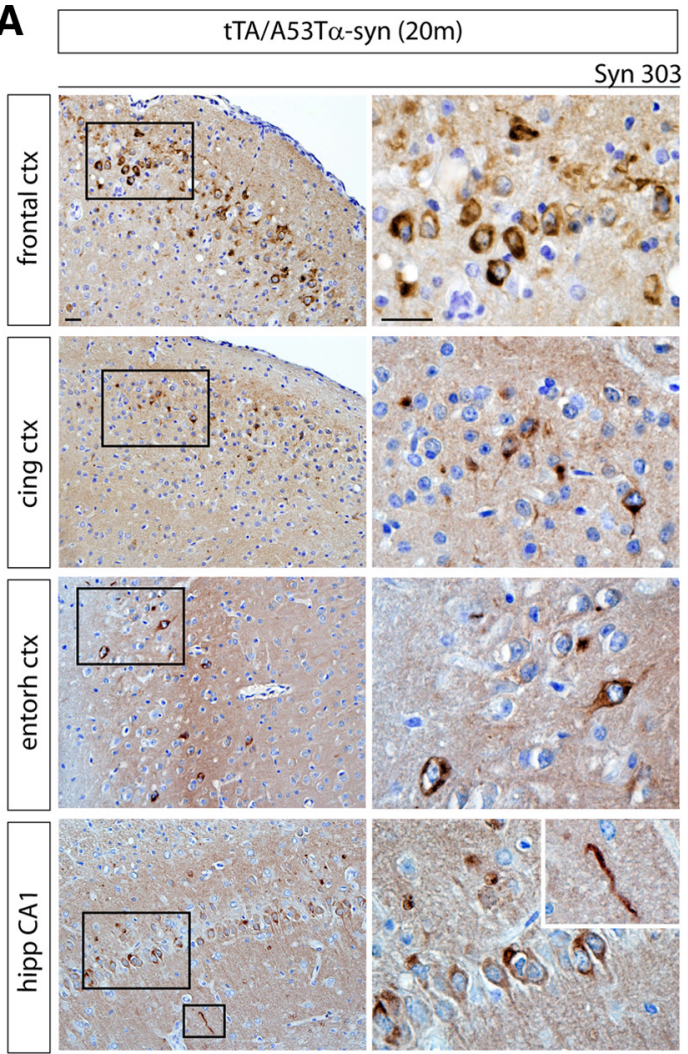

D

$4 \mathrm{mo}$<smiles>C1=C2CCC3CCCC(C1)C3CC2</smiles>

mo<smiles>C1=C2CC3CCCC(C2)C(C1)C3</smiles>

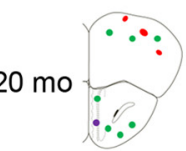
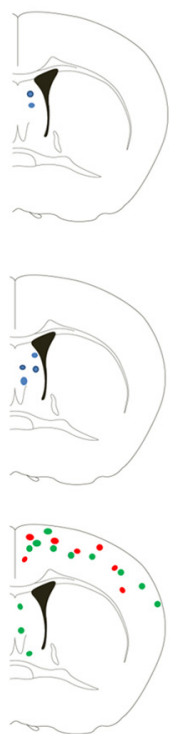

B
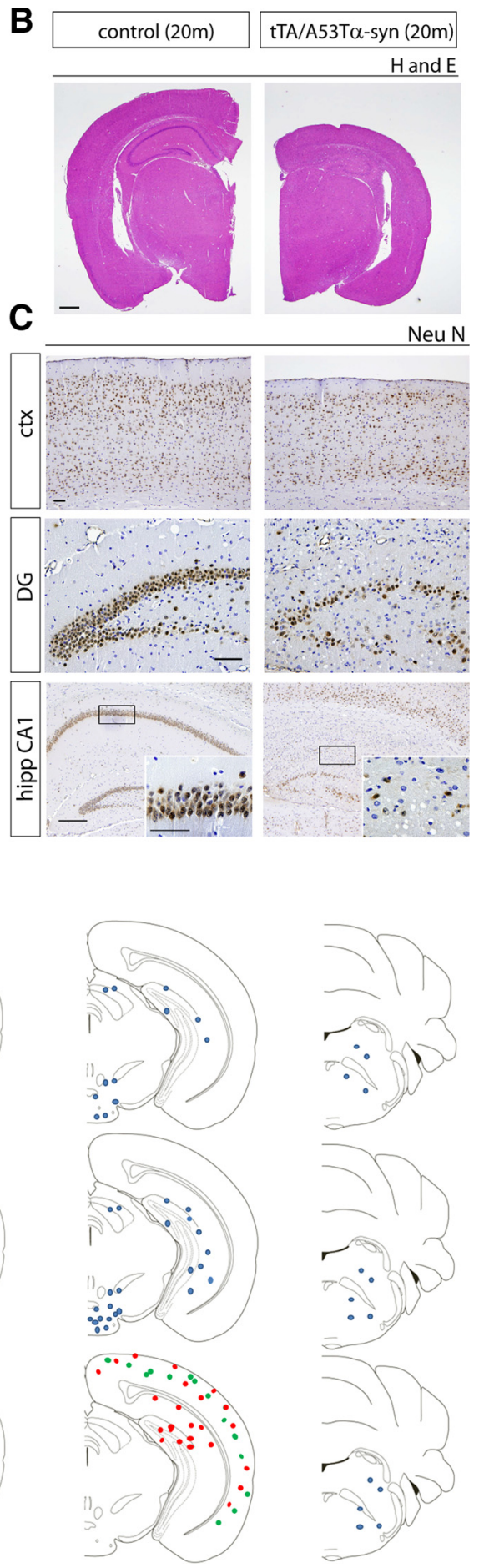

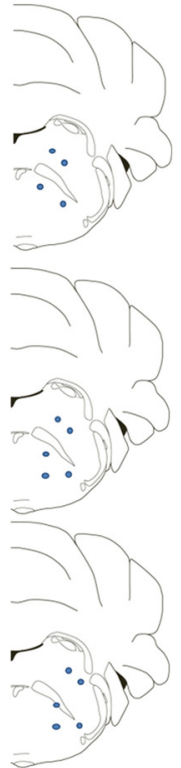

Figure 2. Cytoplasmic accumulation of $\alpha$-syn and neuronal loss in the cortex and hippocampus. A, Paraffin sections of the frontal cortex (frontal ctx), cingulate cortex (cing ctx), entorhinal cortex (entorh ctx), and hippocampal CA1 (hipp CA1) areas from 20-month-old tTA/A53T $\alpha$-syn mice were stained with anti-syn antibody, Syn $303(n=6)$. Boxed areas in the left panels indicate magnified areas in the right panels. Brain sections (coronal) from the control (tTA monogenic) or tTA/A53 $\alpha$-syn bigenic mice $(n=6)$ at the level of hippocampus were stained with hematoxylin and eosin (H and $\mathrm{E})(\boldsymbol{B})$, or antibody against NeuN (brown) (C). Boxed areas in $\boldsymbol{C}$ indicate where the magnified images in the insets were taken. $\boldsymbol{D}$, Diagrammatic summary of $\alpha$-syn pathology distribution in tTA/A53T $\alpha$-syn mice. Blue dots represent synaptic/neuritic pathology, green dots represent cytoplasmic pathology, and red dots represent cell loss. Coronal sections of the one hemisphere are illustrated for simplicity (from left to right, each diagram is taken at the level of bregma $2.8 \mathrm{~mm}, 0.14 \mathrm{~mm},-2.06 \mathrm{~mm},-3.08 \mathrm{~mm}$, and $-5.68 \mathrm{~mm}$ based on the mouse brain atlas by Paxinos and Franklin, 2011). ctx, Cortex; DG, dentate gyrus; hipp CA1, hippocampal CA1. Scale bars: $A, 25 \mu \mathrm{m} ; \boldsymbol{B}, 500 \mu \mathrm{mm} ; C, 200 \mu \mathrm{m}$.

and hippocampus (data not shown) (Fig. 2C), and no cytoplasmic accumulation of $\alpha$-syn was observed in these areas. Notably, familial DLB is associated with severe neuronal loss in hippocampal CA2/3 areas similar to what we observed in old tTA/A53T $\alpha$ syn mice (Ohara et al., 1999; Spira et al., 2001; Kotzbauer et al.,
2004). A summary of the region and age-dependent accumulation of $\alpha$-syn pathology is shown in Figure $2 D$.

tTA/WT $\alpha$-syn mice (line 7) developed less severe $\alpha$-syn accumulations within neurons in the similar areas (i.e., septum, cingulate cortex, subthalamic nucleus, mammillary body, and 

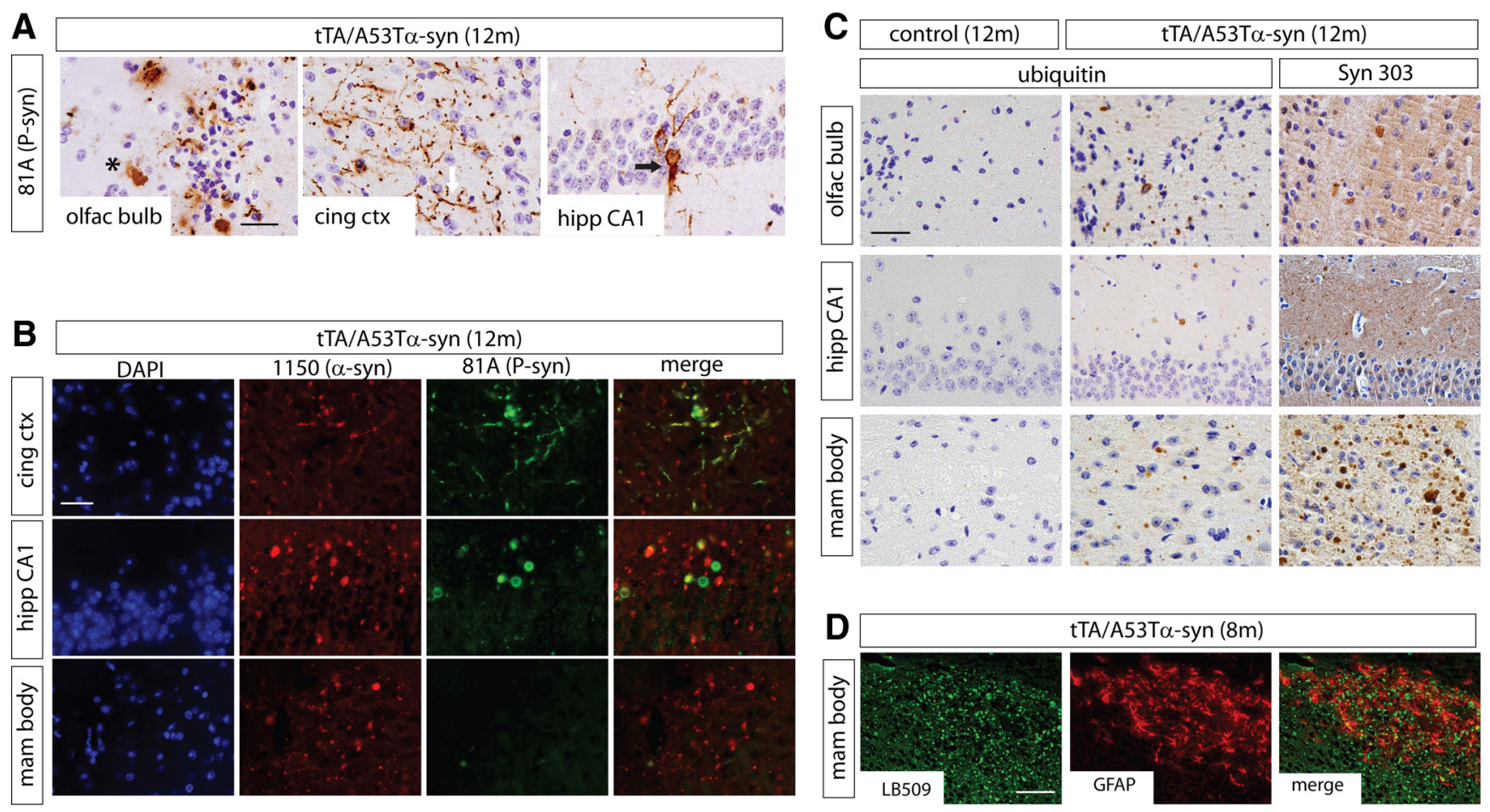

Figure 3. Characterization of $\alpha$-syn pathology. A, Paraffin sections of the olfactory bulb (olfac bulb), cingulate cortex (cing ctx), and hippocampal CA1 (hipp CA1) area from the tTA/A53T $\alpha$-syn bigenic mice (12 months) ( $n=5$ ) were stained with antibody against $\alpha$-syn phosphorylated at Ser129 (81A). Representative dot-like (asterisk), neuritic (white arrow), and cytoplasmic (black arrow) pathologies are marked. $\boldsymbol{B}$, Paraffin sections of the indicated brain regions from the TTA/A53T $\alpha$-syn bigenic mice (12 months) were double stained with antibodies to nonphosphorylated (Syn 1150) or phosphorylated (81A) $\alpha$-syn. DAPI was used for nuclear counterstaining. C, Paraffin sections of the indicated brain areas from the control (A53T $\alpha$-syn monogenic) and tTA/A53T $\alpha$-syn bigenic mice were stained with anti-ubiquitin antibody and Syn 303. D, Mammillary body sections were stained with LB509 (anti-human $\alpha$-syn) and anti-GFAP antibody (astrocytic marker). Scale bars: in $\boldsymbol{A}, 25 \mu \mathrm{m} ; \boldsymbol{B}, 30 \mu \mathrm{m} ; \boldsymbol{C}, 25 \mu \mathrm{m} ; \boldsymbol{D}, 50 \mu \mathrm{m}$.

brainstem) at 8 months or later but not in the hippocampus (data not shown). Moreover, severe neuronal loss like that seen in tTA/ A53T $\alpha$-syn mice was not observed in WT $\alpha$-syn lines at 20 months (data not shown).

\section{Abnormally accumulated $\alpha$-syn is phosphorylated, ubiquitinated, and leads to gliosis}

We next asked whether abnormally accumulated $\alpha$-syn acquired disease-associated posttranslational modification such as phosphorylation or ubiquitination. Ser129-phosphorylation is a widely recognized pathological component of $\alpha$-syn inclusions in human cases as well as in animal models, although its role in pathogenesis is not clear (Fujiwara et al., 2002; Kahle et al., 2002; Chen and Feany, 2005). We stained brain sections from tTA/ A53T $\alpha$-syn mice with an antibody that specifically recognizes $\alpha$-syn when it is phosphorylated at the Ser 129 residue ( $\mathrm{P}$-syn/81A antibody) (Waxman and Giasson, 2008). We found that the olfactory bulb, cingulate cortex, and hippocampus from these mice contained phosphorylated $\alpha$-syn (Fig. 3A), whereas sections from A53T $\alpha$-syn monogenic mice did not show similar staining (data not shown). However, P-syn/81A did not appear to recognize the full extent of pathology as recognized by other $\alpha$-syn antibodies (see below).

To better understand the role of $\alpha$-syn phosphorylation in the pathogenesis of disease pathology, we generated a novel polyclonal antibody specific to nonphosphorylated $\alpha$-syn (Syn 1150) that otherwise recognizes the same region of $\alpha$-syn as the P-syn/ 81A antibody (data not shown). We compared P-syn/81A staining with Syn 1150 staining in 12-month-old mice and observed three different patterns of phosphorylated versus nonphosphorylated $\alpha$-syn pathology. The first pattern, as seen in the cingulate cortex, consisted of colabeling of $\alpha$-syn pathology with both $\mathrm{P}$-syn/81A and Syn 1150, suggesting that the $\alpha$-syn accumulations in this area are a mixture of phosphorylated and nonphosphorylated forms of $\alpha$-syn (Fig. 3B). The second pattern, as seen in the hippocampus, consisted of P-syn/81A and Syn 1150 labeling of $\alpha$-syn pathology with little or no overlap between the two (Fig. 3B). Finally, as seen in the mammillary body, $\alpha$-syn pathologies were only labeled with Syn 1150 and largely negative for $\mathrm{P}$-syn/81A, indicating that $\alpha$-syn pathology in this area is not phosphorylated (Fig. 3B). At 20 months, $\alpha$-syn pathology was nearly all P-syn/81A positive with limited Syn 1150 immunoreactivity (data not shown). This analysis indicates that $\alpha$-syn pathology in our mouse model shows regional difference in its phosphorylation status, supporting the notion that phosphorylation is not an absolute requisite for $\alpha$-syn accumulation but emerges after $\alpha$-syn pathology forms and appears to be a marker of advanced pathology.

In $\mathrm{PD}$, as with other neurodegenerative disease proteins, $\alpha$-syn in LBs also is posttranslationally conjugated to ubiquitin (Kuzuhara et al., 1988; Lennox et al., 1989; Love and Nicoll, 1992; Gómez-Tortosa et al., 2000; Sampathu et al., 2003). This suggests a possible link between pathological protein-aggregation events and dysfunction of the ubiquitin/proteasome system. For this reason, we asked whether abnormal accumulations of $\alpha$-syn in our mice were ubiquitinated by staining brain sections with an antibody specific to ubiquitin. Olfactory bulb, hippocampal CA1, and mammillary body neurons from tTA/A53T $\alpha$-syn mice showed positive ubiquitin staining, in contrast to A53T $\alpha$-syn monogenic mice (Fig. 3C). Comparing immunostaining of $\alpha$-syn and ubiquitin on adjacent sections, we found that only a small subset of $\alpha$-syn pathology was ubiquitinated (Fig. 3C). Together, 
A

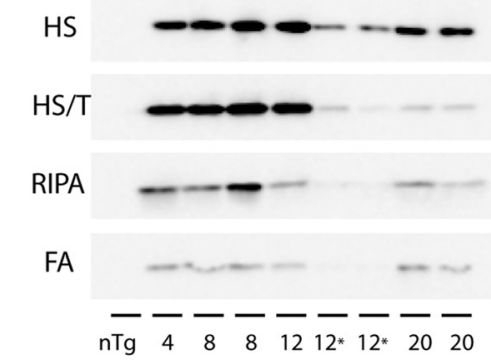

B
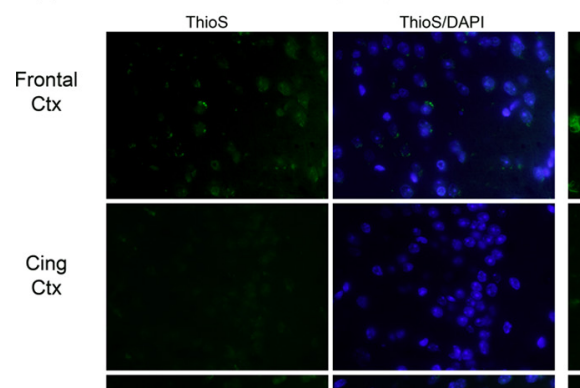

Entorh
Ctx
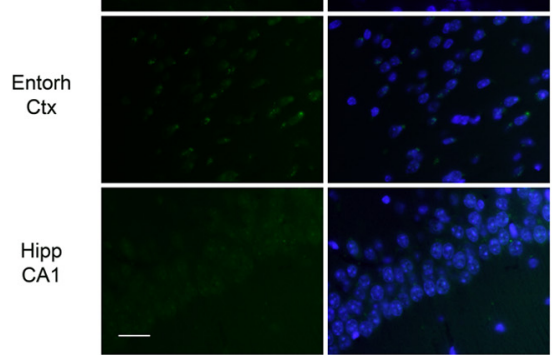

Figure 4. Solubility of human $\alpha$-syn in tTA/A53T $\alpha$-syn mice. $\boldsymbol{A}$, Cortical and hippocampal lysates from nTg or tTA/A53T $\alpha$-syn bigenic mice at different ages were sequentially extracted (see Materials and Methods), and each sample was immunoblotted with LB509 (human-specific anti- $\alpha$-syn antibody). Each number indicates the age of tTA/A53T $\alpha$-syn bigenic mice in months (m). ${ }^{*}$ Dox treatment for 3 months (from 9 months to 12 months). Note more insoluble $\alpha$-syn in 20-month-old mice (hippocampus FA blot was exposed longer for better comparison). $\boldsymbol{B}$, Cytoplasmically accumulated $\alpha$-syns are Thioflavin $\mathrm{S}$ (Thio S) positive. Sections of the frontal cortex (Frontal Ctx), cingulate cortex (Cing Ctx), entorhinal cortex (Entorh Ctx), and hippocampal CA1 (Hipp CA1) area from the 20-month-old control (tTA monogenic) and tTA/A53T $\alpha$-syn mice were stained for Thio S (green). DAPI (blue) was used for nuclear counterstaining. Scale bar, $20 \mu \mathrm{m}$.

these data suggest that $\alpha$-syn in our mice undergoes diseaseassociated posttranslational modifications by ubiquitination, albeit to a modest degree.

The presence of these pathologic alterations prompted us to test whether $\alpha$-syn pathology in the brain leads to astrogliosis. At 8 months, GFAP staining in the mammillary body of the tTA/ A53T $\alpha$-syn mice showed that $\alpha$-syn pathology was associated with reactive astrogliosis (Fig. $3 D$ ). As expected, gliosis was detected in more areas at 12 months and became more severe and widespread at 20 months when overt neuron loss and cerebral atrophy was evident (data not shown). These data suggest that abnormal accumulation of $\alpha$-syn in the synaptic process (i.e., at $8-12$ months) is neurotoxic and triggers gliosis.

Next, we examined the biochemical solubility of accumulated $\alpha$-syn. Sequential extraction was performed using brain lysates prepared from the cortex and hippocampus with a series of buffers with increasing strength of protein solubilization (HS, 1\% Triton X-100 in HS, RIPA, and FA or 2\% SDS). Most of the $\alpha$-syn from 4- to 12-month-old tTA/A53T $\alpha$-syn mice was detected in the HS and HS/T fractions, with small amounts in the RIPA and very little in the FA fractions (Fig. $4 A$ ). Similar results were obtained with mammillary body lysates from tTA/WT $\alpha$-syn mice
(12 months) (data not shown). In contrast, at 20 months, despite severe cell loss and therefore reduced amounts of $\alpha$-syn in the HS and HS/T fractions, insoluble $\alpha$-syn in the FA fraction is increased. These biochemical analyses are consistent with Thioflavin S (ThioS) staining of $\alpha$-syn pathology. In 4 - to 12 -month-old mice, the dot-like or neuritic $\alpha$-syn pathology in different brain areas is negative for Thios (data not shown). In contrast, cytoplasmic $\alpha$-syn pathology in 20month-old mice is positive for ThioS (Fig. $4 B)$. Thus, $\alpha$-syn pathology in younger (4-12 months) mice represents early, soluble neuritic, and synaptic accumulations, which over time progress to become insoluble cytoplasmic inclusions at 20 months.

\section{Hippocampal A53T $\alpha$-syn accumulation is associated with memory impairment in tTA/A53T $\alpha$-syn mice}

Cognitive impairment is a major consequence of LB disorders (Gross et al., 2008; Hanson and Lippa, 2009). To test the effect of abnormal $\alpha$-syn accumulation on cognitive function, we performed associative memory tests by analyzing fearconditioning behavior. We examined both contextual and cued fear memory in the four different genotypes of mice: $\mathrm{nTg}$, A53T $\alpha$-syn, tTA, and tTA/A53T $\alpha$-syn. tTA/A53T $\alpha$-syn mice showed significantly impaired contextual fear memory compared with the other three genotypes at 8 months [62.65 $\pm 8.46(\mathrm{nTg}), 60.75 \pm$ 8.85 (syn), $55.47 \pm 5.53$ (tTA), $10.24 \pm$ 3.10 (tTA/syn): the values are displayed as mean \pm SEM)], but not at 4 months $[75.72 \pm 7.70(\mathrm{nTg}), 61.63 \pm 7.72(\mathrm{syn})$, $76.15 \pm 5.12$ (tTA), $40.28 \pm 12.64$ (tTA/syn)] (Fig. 5A). In contrast, tTA/WT $\alpha$-syn mice did not show any significant impairment at 8 months $[59.90 \pm 10.14(\mathrm{nTg}), 47.79 \pm 5.29$ (syn), $71.78 \pm 8.24$ (tTA), $58.84 \pm 12.15$ (tTA/syn)] (Fig. 5A). In cued fear conditioning, 8-month-old tTA/A53T $\alpha$-syn mice showed a nonsignificant trend toward showing some memory impairment $[71.86 \pm 7.15(\mathrm{nTg}), 86.04 \pm 4.06(\mathrm{syn}), 80.69 \pm 5.16(\mathrm{tTA})$, $59.27 \pm 10.50(\mathrm{tTA} / \mathrm{syn})]$, and 4-month-old tTA/A53T $\alpha$-syn $[87.13 \pm 3.98(\mathrm{nTg}), 87.22 \pm 2.90(\mathrm{syn}), 89.00 \pm 3.48(\mathrm{tTA})$, $81.88 \pm 6.80(\mathrm{tTA} / \mathrm{syn})]$ and 8 -month-old tTA/WT $\alpha$-syn $[82.73 \pm 5.65(\mathrm{nTg}), 75.71 \pm 6.00(\mathrm{syn}), 77.61 \pm 5.76(\mathrm{tTA})$, $78.16 \pm 8.83$ (tTA/syn)] mice did not show any significant impairment (Fig. $5 B$ ). It is known that contextual fear memory is heavily dependent on intact hippocampal function, whereas cued fear memory requires an intact amygdala and is less dependent on the hippocampus (Kim and Fanselow, 1992). Indeed, hippocampi from tTA/A53T $\alpha$-syn mice showed $\alpha$-syn pathology in synaptic areas, including oriens layers, stratum radiatum, and the molecular layer of the dentate gyrus (Figs. 1A, 6), which increased in severity from 4 months to 8 months (data not shown) (Figs. $1 A, 6$ ). In contrast, at this age, abnormal $\alpha$-syn accumulation was not seen in the amygdala (data not shown). Thus, tTA/ 

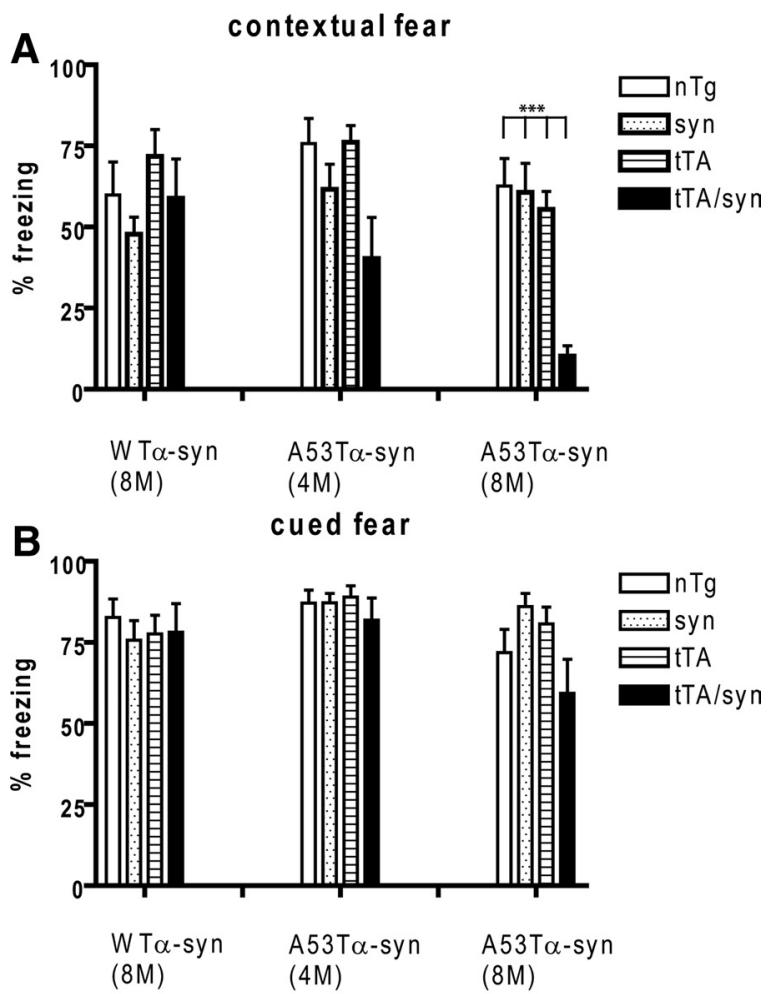

C Contextual fear vs. hpc pathology

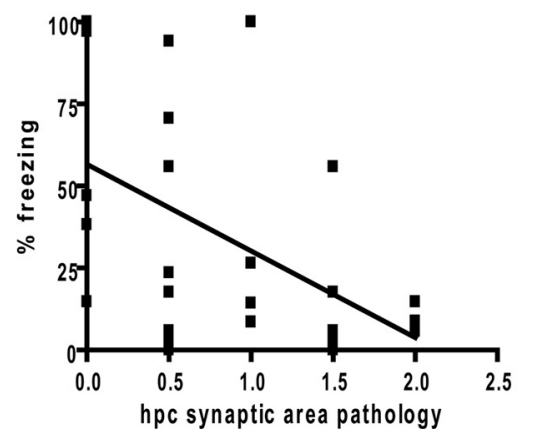

Figure 5. Contextual fear memory impairment in bigenic mice and its correlation with $\alpha$-syn pathology in the hippocampus. $A$, Contextual fear memory was measured by percentage time freezing with four different genotypes of line 7 (WT $\alpha$-syn) at 8 months ( $n=10,9,10,8$ for $\mathrm{nTg}$, syn, tTA, and tTA/syn mice, respectively) and line 33 (A53T $\alpha$-syn) at 4 months ( $n=10,11$, $13,8)$ and 8 months $(n=9,12,8,10)$. The data are displayed as mean \pm SEM (see the text for the numeric values). ${ }^{* * *} p<0.0001$, one-way ANOVA with Tukey's multiple comparison post hoc analysis. $\boldsymbol{B}$, Cued fear memory was measured by percentage time freezing with the same mice used in $\boldsymbol{A}$. The data are displayed as mean \pm SEM (see the text for the numeric values), one-way ANOVA. C, To examine the relationship between the severity of contextual fear memory impairment and the severity of $\alpha$-syn pathology in the hippocampus (hpc), the percentage time freezing was plotted against $\alpha$-syn pathology score in the hippocampus for each bigenic mouse $(n=32)$. There is a statistically significant correlation between impaired memory and $\alpha$-syn pathology in the hippocampus $\left(r^{2}=0.2414, p=0.0092^{*}\right)$. Statistically significant.

A53T $\alpha$ mice showed age-dependent memory impairments primarily linked to hippocampal function.

Our findings that abnormal $\alpha$-syn accumulation was detected mainly in limbic areas including the hippocampus and that tg mice with significant $\alpha$-syn pathology showed impaired memory function led us to investigate whether there was any correlation between $\alpha$-syn pathology in the limbic areas and cognitive impairment (indicated as percentage freezing). $\alpha$-Syn pathology in multiple brain regions of tTA/A53T $\alpha$-syn mice $(n=32)$ detected by immunohistochemistry using synuclein antibody (Syn 303) was graded on a scale of 0-3 (0: no or little, 1: mild, 2: moderate, 3: severe pathology) (data not shown). The pathology grade in each area of the brain and the freezing score of the contextual fear memory test were used for correlation analysis. $\alpha$-Syn pathology in the hippocampus and mammillary body showed a statistically significant negative correlation with contextual fear memory (data not shown) (Fig. 5C). In contrast, $\alpha$-syn pathologies in other areas such as the olfactory bulb did not show a significant correlation with memory function (data not shown). These data indicate that $\alpha$-syn pathology in limbic areas, especially in the hippocampus, is associated with impaired cognitive function, consistent with the known role of the hippocampus and related limbic structures in memory function and the known involvement of these structures in dementias linked to $\alpha$-syn.

Suppression of $\alpha$-syn transgene expression clears pre-existing $\alpha$-syn pathology and prevents gliosis in the hippocampus

There are no disease-modifying therapies for LB-related disorders ( $\alpha$-synucleinopathies). Indeed, it is not even known whether targeting $\alpha$-syn can inhibit or even reverse $\alpha$-syn brain pathology or cognitive decline. We hypothesized that suppression of $\alpha$-syn transgene expression can clear pre-existing $\alpha$-syn pathology. To test this hypothesis, mice were treated with dox diet starting at 9 months for 3 months and analyzed at 12 months (12 month ${ }^{\text {dox9-12m }}$ mice). These mice were compared with mice in which transgene expression was maintained until sacrifice at 8 months or 12 months. Abnormal $\alpha$-syn accumulations were detected in the hippocampus (oriens layer and stratum radiatum of the CA1 and stratum lucidum of the CA3) and in the dentate gyrus molecular layer of the untreated mice at 8 months, which progressed in severity at 12 months (Fig. 6). In contrast, hippocampal $\alpha$-syn accumulation was not detected in the dox-treated 12 month $^{\text {dox } 9-12 \mathrm{~m}}$ mice (Fig. 6), suggesting that suppression of transgene expression for 3 months is sufficient not only to inhibit progression but also to clear hippocampal $\alpha$-syn pathology.

Interestingly, clearance of $\alpha$-syn pathology was regionspecific, as some areas of the brain, including the mammillary bodies, olfactory bulb and septum, did not exhibit reversal of $\alpha$-syn pathology, although progression of pathology was clearly arrested (data not shown). This observation suggests that there may be regional differences either in the characteristics of the pathologic deposits or in the capability of specific neurons to clear pathological $\alpha$-syn.

We also examined the extent of gliosis in the hippocampus of dox-treated mice compared with untreated mice. When transgene expression is maintained, the extent of gliosis in the 8-month-old bigenic mice detected by GFAP staining was mild relative to control mice (data not shown). However, in 12month-old bigenic mice, reactive astrogliosis was pronounced, consistent with $\alpha$-syn-mediated neurodegeneration. In contrast, in 12 month ${ }^{\text {dox } 9-12 \mathrm{~m}}$ mice, the extent of gliosis was comparable to that in 8-month-old untreated bigenic mice, suggesting that suppression of $\alpha$-syn prevented reactive gliosis.

\section{Suppression of $\alpha$-syn transgene reverses synaptic defects and} improves memory function

Elevation of $\alpha$-syn level has been suggested to mediate synaptic dysfunction (Larsen et al., 2006; Garcia-Reitböck et al., 2010; Nemani et al., 2010; Scott et al., 2010). We explored whether A53T mutant human $\alpha$-syn expression would lead to synaptic defects in mice and whether any of these defects could be reversed by suppression of $\alpha$-syn expression. First, we examined the expression of various synaptic proteins in the mossy fiber terminals, 


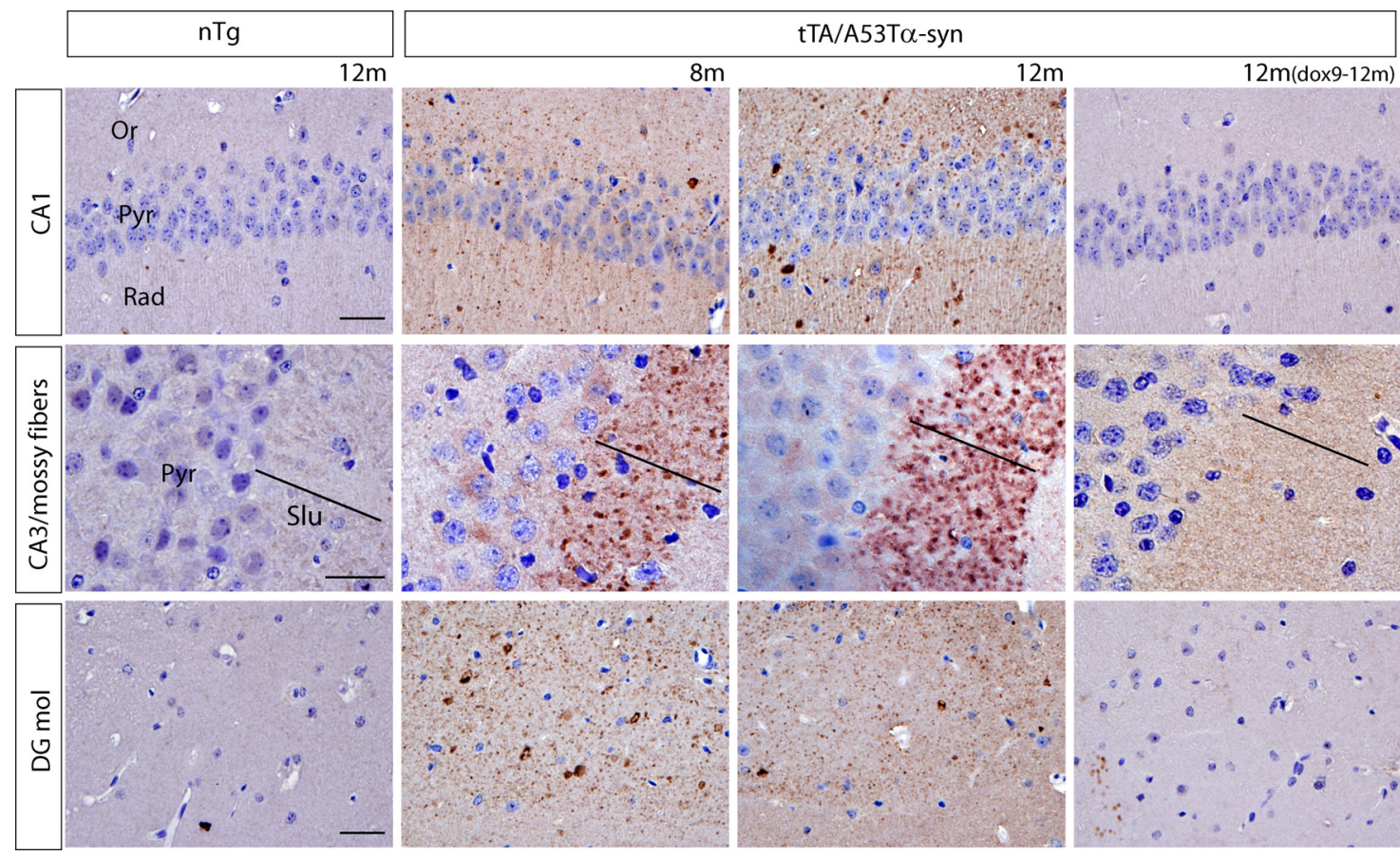

Figure 6. Suppression of $\alpha$-syn transgene clears pre-existing pathology in the hippocampus. Coronal sections of the hippocampal CA1, CA3/mossy fibers, and dentate gyrus molecular layer (DG mol) from nTg (12 month) and tTA/A53T $\alpha$-syn mice (8 month, 12 month, 12 month ${ }^{\text {dox9-12m }}$ ) were immunostained with Syn 1150 to label $\alpha$-syn pathology. Eight-month-old and 12 -month-old bigenic mice show granule, dot-like $\alpha$-syn pathology in the Oriens layer of the hippocampus (Or), stratum radiatum (Rad), and stratum lucidum (SLu; mossy fibers from dentate gyrus granule cells course through this stratum in CA3) of the hippocampus and DG mol. However, dox-treated 12-month-old bigenic mice show comparable level to control mice ( $n=5-8$ per group). Each line indicates the thickness of the SLu. Pyr, Pyramidal cell layers. Scale bar, $20 \mu \mathrm{m}$.

which are the axonal terminals of the projections from the dentate gyrus to CA3. Significant reductions of presynaptic vesicle proteins including synaptophysin, $\operatorname{CSP} \alpha$, synaptotagmin, synapsin I, and synaptobrevin 2 (vamp2) were detected by immunohistochemistry at 8 months, and this reduction was more severe at 12 months (data not shown) (Fig. $7 A, B$ ). These results were in contrast with t-SNARE components localized in the synaptic plasma membrane such as syntaxin and SNAP-25, which were not detectibly reduced in the mossy fiber terminals (Fig. 7C). However, in addition to its normal synaptic localization within the mossy fibers, abnormal mislocalization of syntaxin was observed in the pyramidal cell layers of the CA2/3 area (at 8 months and greater at 12 months) (Fig. $7 C$, arrows). These overt synaptic defects were not observed in 4-month-old tTA/A53T $\alpha$-syn or in 8 -month-old WT/A53T $\alpha$-syn mice (data not shown). Together, these data indicate that $\alpha$-syn accumulation in the mossy fibers leads to disruption in synaptic vesicles and results in mislocalization of syntaxin.

To demonstrate that these structural synaptic changes are dependent on $\alpha$-syn, we examined the effects of suppressing $\alpha$-syn expression on the mossy fiber terminals. Inhibiting $\alpha$-syn expression with the dox diet completely reversed the mossy fiber terminal defects, as determined by normal staining for synaptic vesicle proteins and syntaxin (Fig. 7A-C). Thus, these data indicate that the synaptic defects in 8-month-old and 12-month-old bigenic mice are dependent on $\alpha$-syn transgene expression, and these defects can be reversed by suppression of $\alpha$-syn expression.

We next determined whether clearance of $\alpha$-syn pathology and reversal of synaptic defects in the hippocampus by suppressing $\alpha$-syn expression would translate into improvements in memory function. We measured the fear-conditioned memory of the dox-treated (12 month $\left.{ }^{\text {dox } 9-12 \mathrm{~m}}\right)$ and untreated mice (12 month) (Fig. 8). We found that dox diet alone affected fear- conditioning behavior (globally reducing freezing scores even in control nTg mice). Thus, all four genotypes were treated with dox for 3 months and then tested for cognitive function. Although dox-treated bigenic mice $\left(12\right.$ month $\left.^{\text {dox } 9-12 \mathrm{~m}}\right)$ tended to show reduced freezing scores relative to dox-treated $\mathrm{nTg}$, syn, or tTA mice, this effect was not statistically significant $[65.35 \pm 12.02$ (nTg), $51.28 \pm 8.48$ (syn), $67.68 \pm 7.14$ (tTA), $37.88 \pm 9.65$ (tTA/syn)]. In contrast, normal chow-fed 12-month-old bigenic mice showed statistically significant impairment in contextual fear memory compared with normal chow-fed nTg, syn, or tTA mice, as expected $[82.04 \pm 4.52(\mathrm{nTg}), 71.73 \pm 6.34$ (syn), $74.71 \pm 5.76$ (tTA), $28.52 \pm 11.78$ (tTA/syn)]. Finally, there were no significant differences between genotypes of either normal chow-fed or dox-fed mice in cued fear memory, as expected. Together, these results suggest that clearance of $\alpha$-syn pathology and reversal of synaptic defects by suppression of $\alpha$-syn expression resulted in improved memory function.

\section{Discussion}

In the present study, we analyzed tetracycline-controllable $\alpha$-syn tg mice to model the pathogenesis of DLB. These tg mice developed progressive $\alpha$-syn pathology mainly in the limbic areas, with a distribution similar to that observed in affected human brains. In these animals, we observed age-dependent defects in synaptic structure and impairment in memory function. Remarkably, $\operatorname{tg} \alpha$-syn suppression resulted in clearance of $\alpha$-syn pathology and restoration of structural synaptic defects in the hippocampus. Furthermore, suppression of $\alpha$-syn expression led to a mild improvement in memory function.

The pathological diagnosis of DLB requires analysis for the presence and distribution of LBs and related pathology. Immunohistochemical staining for $\alpha$-syn is the most sensitive and specific method currently available for detecting LBs and related 

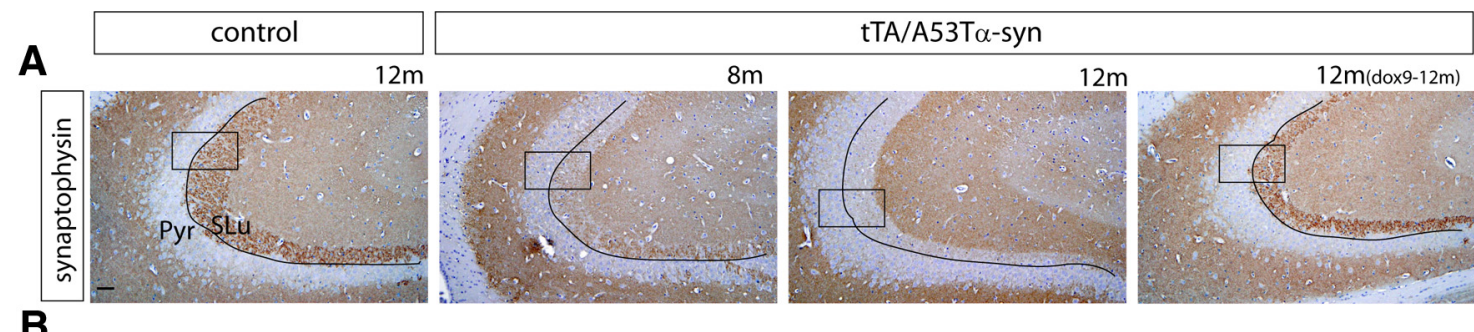

B
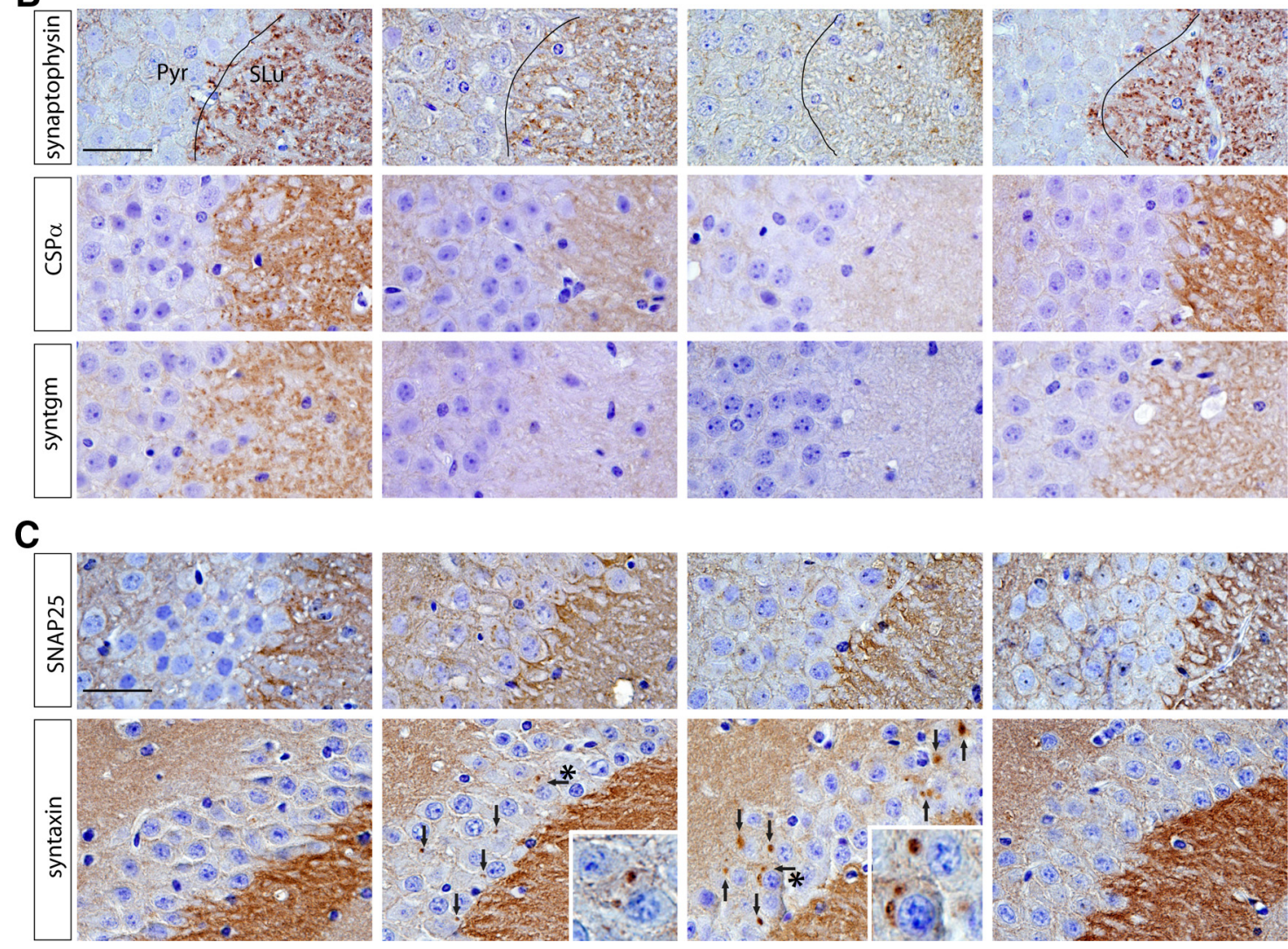

Figure 7. Suppression of $\alpha$-syn transgene reverts structural synaptic defects. $A$, Representative low-magnification images of the hippocampal sections from control (A53T $\alpha$-syn) (12 month) or TTA/A53T $\alpha$-syn mice (8 month, 12 month, 12 month ${ }^{\text {dox } 9-12 m}$ ) stained with synaptophysin ( $n=3$ per group). Boxed areas indicate the representative areas from where the images in $B$ were taken. Curved lines in $\boldsymbol{A}$ and $\boldsymbol{B}$ denote boundaries between pyramidal cell (Pyr) layers and stratum lucidum (SLu). B, Representative images of the hippocampal CA3/mossy fiber areas stained with synaptic vesicle proteins, synaptophysin, (SP $\alpha$, and synaptotagmin (syntgm) ( $n=3$ per group). Eight-month-old and 12-month-old bigenic mice show reduced staining, whereas dox-treated 12 -monthold bigenic mice show comparable level to monogenic control. C, Representative images of the hippocampal CA3/mossy fiber areas stained with SNAP25 and syntaxin (t-SNAREs) ( $n=3$ per group). Note abnormal accumulation of syntaxin in the pyramidal layers of the CA3 (arrows). Each inset is an enlarged image of the area indicated as arrow with asterisk. Scale bars: $A, 50 \mu \mathrm{m} ; \boldsymbol{B}, 40 \mu \mathrm{m}$; C, $40 \mu \mathrm{m}$.

pathology (Spillantini et al., 1997; McKeith et al., 2005). Three patterns of LB pathology are recognized: brainstem predominant, limbic (transitional), and diffuse neocortical types. In the brainstem predominant type, $\alpha$-syn pathology is distributed mainly in the brainstem nuclei (locus ceruleus, substantia nigra, and ninth and 10th cranial nerve nucleus), with little or no pathology in the limbic areas and neocortex. In the limbic or transitional type, $\alpha$-syn pathology is detected in the basal forebrain/ limbic areas (including cingulate cortex, transentorhinal cortex, and amygdala), as well as in the brainstem, with limited pathology in the neocortex. Finally, in the diffuse neocortical type, $\alpha$-syn pathology is also detected in neocortex. In this regard, our mouse model at 4 months and 8 months most resembles the limbic (transitional) pattern of LB disease because $\alpha$-syn pathology was found in limbic areas with little or no pathology in the neocortex. At 20 months, $\alpha$-syn accumulation was also detected in the neocortex akin to the neocortical pattern of $\alpha$-syn pathol- ogy. We observed very limited neuritic $\alpha$-syn pathology within the brainstem, which may represent caudal projections of forebrain neurons because the CaMKII $\alpha$ promoter drives expression mainly in the forebrain. It is also worth noting that severe neuron loss in the hippocampal CA2/3 areas has been described in familial dementia cases, similar to the pattern of neurodegeneration we observed in 20-month-old tTA/A53T $\alpha$-syn mice (Ohara et al., 1999; Spira et al., 2001; Kotzbauer et al., 2004). Together, these results indicate that our mouse model is remarkably similar to the human disease.

Abnormal $\alpha$-syn phosphorylation at Ser129 is a reliable marker of pathology in end-stage human tissues. However, the role of $\alpha$-syn phosphorylation in fibril formation is not clear, and whether phosphorylation promotes or inhibits fibril formation remains controversial (Fujiwara et al., 2002; Paleologou et al., 2008). Furthermore, the presence of nonphosphorylated counterpart of phosphorylated Ser 129 of $\alpha$-syn in pathologic accumu- 

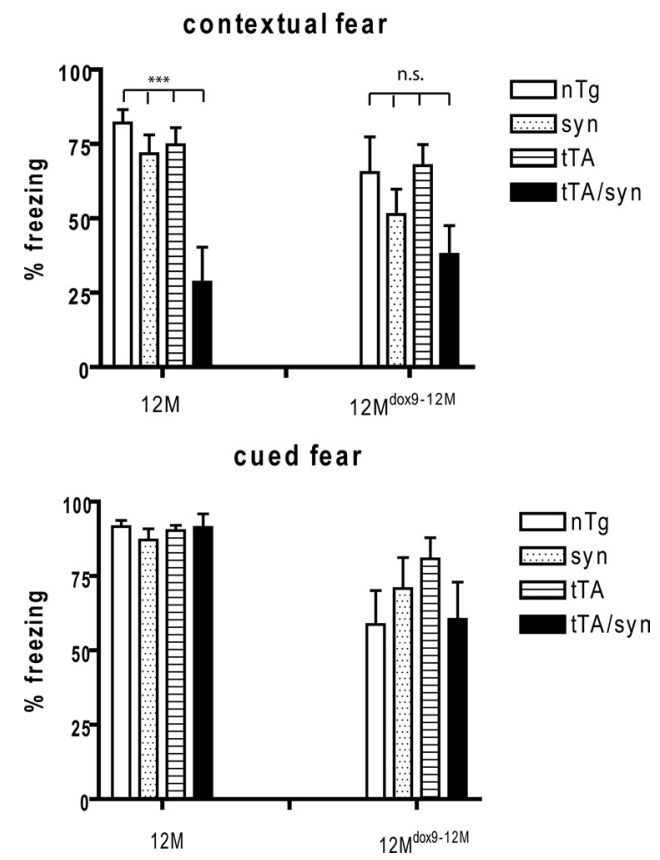

Figure 8. Suppression of $\alpha$-syn transgene improves memory function. Contextual and cued fear memory were measured by percentage time freezing in 12-month-old bigenic mice with $\left(12 \mathrm{~m}^{\mathrm{dox} 9-12 \mathrm{~m}}\right)(n=8,10,10,9$ for $\mathrm{nTg}$, syn, $\mathrm{tTA}$, and $\mathrm{tTA} /$ syn mice, respectively) or without $(12 \mathrm{~m})(n=12,13,10,9)$ dox treatment for 3 months. For contextual fear memory, there is no significant (n.s.) difference in percentage freezing among dox-treated groups, whereas there is significant difference among untreated groups (bigenic mice show significant reduction in percentage freezing). The data are displayed as mean \pm SEM (see the text for the numeric values) ( ${ }^{* * *} p<0.0001$, one-way ANOVA with Tukey's multiple comparison post hoc analysis). For cued fear memory, there is no significant difference in either group. The data are displayed as mean \pm SEM (see the text for the numeric values).

lations has not been examined. Using a novel nonphosphorylated $\alpha$-syn antibody specific for the 125-129 peptide YEMPS, we found that Ser 129 phosphorylation of $\alpha$-syn is not a requisite for $\alpha$-syn accumulation in mice, and that both phosphorylated and nonphosphorylated epitopes are found in discrete but often overlapping patterns. Although Ser129 $\alpha$-syn phosphorylation is not required for $\alpha$-syn accumulation, at least a subset of $\alpha$-syn accumulations was positive for the phospho-specific 81A antibody even at early time points, and $81 \mathrm{~A}$ immunoreactivity increased progressively over time such that advanced stages are characterized by widespread phosphorylation of $\alpha$-syn. Further analysis is clearly required to determine whether nonphosphorylated $\alpha$-syn can be seen in human tissues and whether the proportion and distribution of nonphosphorylated versus phosphorylated $\alpha$-syn change with disease progression.

The impairment of the associative memory function observed in our mouse model correlates with the abnormal accumulation of $\alpha$-syn in limbic areas, especially in the hippocampus. Structural synaptic defects in the hippocampus (i.e., disrupted syntaxin localization and a reduction in presynaptic vesicle proteins) are the likely anatomic substrate for the memory dysfunction in our mouse model, in particular because younger 4-month-old tTA/A53T $\alpha$-syn or 8-month-old tTA/WT $\alpha$-syn mice with relatively weak $\alpha$-syn pathology did not show any synaptic defects or memory dysfunction. How does tg $\alpha$-syn lead to these synaptic defects in the nerve terminal? First, A53T $\alpha$-syn may inhibit the SNARE complex assembly and thus cause an accumulation of the SNARE component, syntaxin. Supporting this possibility, a recent in vitro study reported that soluble A53T $\alpha$-syn can directly bind to syntaxin 5 and inhibit the formation of four helix bundle of SNARE complex (Thayanidhi et al., 2010). Thus, it is plausible that A53T $\alpha$-syn inhibited assembly of free syntaxin into the SNARE complex, resulting in mislocalization of syntaxin in the hippocampus in our mouse model. In agreement with our findings, mislocalization or altered distribution of syntaxin has been previously described in transgenic mice expressing human A30P $\alpha$-syn or truncated $\alpha$-syn (Garcia-Reitböck et al., 2010). Interestingly, these effects of A53T $\alpha$-syn on SNARE complex formation seem to be the opposite of WT $\alpha$-syn as WT $\alpha$-syn has been recently shown to directly bind synaptobrevin-2/vamp2 (another SNARE protein) and promote SNARE complex assembly (Burré et al., 2010). This nonclassical chaperone activity of $\alpha$-syn seems to be disrupted by the A53T mutation. Given this background, our data in tg mice provide in vivo evidence that A53T $\alpha$-syn may interfere with SNARE machinery assembly, thereby causing vesicle fusion defects.

Second, our observed reductions in presynaptic proteins (synaptophysin, $\operatorname{CSP} \alpha$, synaptotagmin, synapsin I, and vamp2) at the axonal terminal may be due to impairments in normal axonal transport or synaptic targeting of presynaptic proteins. Supporting this possibility, it has been shown that the viral transduction of A53T mutant $\alpha$-syn protein in rat brains diminished levels of various proteins involved in axonal transport (Chung et al., 2009). Another possibility is that the $\alpha$-syn aggregates in the neural processes may physically block the transport of certain presynaptic proteins. Furthermore, multiple studies have implicated vesicular/protein trafficking pathways in the pathogenesis of $\alpha$-synucleinopathies (Cooper et al., 2006; Larsen et al., 2006; Kuwahara et al., 2008; Soper et al., 2008; van Ham et al., 2008; Nemani et al., 2010; Scott et al., 2010). However, because SNAP25 and syntaxin were still found within mossy fiber terminals, the reductions detected in the synaptic vesicle presynaptic proteins were not due to axonal loss.

One of the benefits of using inducible tg mice to model neurodegenerative diseases is the temporal and spatial control of transgene expression. Thus, these models can test whether a pathologic cascade can be stopped or perhaps even reversed. For example, suppression of transgene expression in tTA/APP mice has been reported to arrest amyloid pathology progression, although clearance of pre-existing pathology was not observed (Jankowsky et al., 2005). This study provided significant therapeutic insights in that arresting $\mathrm{A} \beta$ production in Alzheimer's patients could inhibit progression of pathology, and also that early treatment may be necessary because clearance of amyloid deposits was not observed. Another study with tTA/Tau $\mathrm{P}_{\mathrm{P} 01 \mathrm{~L}}$ mice demonstrated that tau transgene suppression improved memory function and stabilized neuron numbers, but it failed to arrest accumulation of NFTs (neurofibrillary tangles) (Santacruz et al., 2005). This study suggests that cognitive impairment can be restored without clearing tau NFTs. However, long-term suppression of $\alpha$-syn expression has not been tested in $\alpha$-syn mouse models. In our model, we were able to circumvent early developmental effects by suppressing transgene expression with doxycycline treatment during development. Also, we were able to study the effects of $\alpha$-syn transgene suppression in mice that already developed pathology, synaptic defects, and memory impairments. We found that suppression of transgene expression cleared $\alpha$-syn pathology in the hippocampus, arrested $\alpha$-syn pathology progression in other brain regions, restored hippocampal synaptic defects, and improved memory function. Thus, together, these data provide important insights into the development of therapies aimed at ameliorating cognitive deficits in 
DLB/PDD patients and provide validation that targeting $\alpha$-syn may be beneficial for LB disorders.

\section{References}

Aarsland D, Beyer MK, Kurz MW (2008) Dementia in Parkinson's disease. Curr Opin Neurol 21:676-682.

Baba M, Nakajo S, Tu PH, Tomita T, Nakaya K, Lee VMY, Trojanowski JQ, Iwatsubo T (1998) Aggregation of alpha-synuclein in Lewy bodies of sporadic Parkinson's disease and dementia with Lewy bodies. Am J Pathol 152:879-884.

Burré J, Sharma M, Tsetsenis T, Buchman V, Etherton MR, Südhof TC (2010) Alpha-synuclein promotes SNARE-complex assembly in vivo and in vitro. Science 329:1663-1667.

Chen L, Feany MB (2005) Alpha-synuclein phosphorylation controls neurotoxicity and inclusion formation in a Drosophila model of Parkinson disease. Nat Neurosci 8:657-663.

Chung CY, Koprich JB, Siddiqi H, Isacson O (2009) Dynamic changes in presynaptic and axonal transport proteins combined with striatal neuroinflammation precede dopaminergic neuronal loss in a rat model of AAV alpha-synucleinopathy. J Neurosci 29:3365-3373.

Cooper AA, Gitler AD, Cashikar A, Haynes CM, Hill KJ, Bhullar B, Liu K, Xu K, Strathearn KE, Liu F, Cao S, Caldwell KA, Caldwell GA, Marsischky G, Kolodner RD, Labaer J, Rochet JC, Bonini NM, Lindquist S (2006) $\alpha$-Synuclein blocks ER-Golgi traffic and Rab1 rescues neuron loss in Parkinson's models. Science 313:324-328.

Duda JE, Giasson BI, Mabon ME, Lee VM, Trojanowski JQ (2002a) Novel antibodies to synuclein show abundant striatal pathology in Lewy body diseases. Ann Neurol 52:205-210.

Duda JE, Giasson BI, Mabon ME, Miller DC, Golbe LI, Lee VM, Trojanowski JQ (2002b) Concurrence of alpha-synuclein and tau brain pathology in the Contursi kindred. Acta Neuropathol 104:7-11.

Fujiwara H, Hasegawa M, Dohmae N, Kawashima A, Masliah E, Goldberg MS, Shen J, Takio K, Iwatsubo T (2002) $\alpha$-Synuclein is phosphorylated in synucleinopathy lesions. Nat Cell Biol 4:160-164.

Garcia-Reitböck P, Anichtchik O, Bellucci A, Iovino M, Ballini C, Fineberg E, Ghetti B, Della Corte L, Spano P, Tofaris GK, Goedert M, Spillantini MG (2010) SNARE protein redistribution and synaptic failure in a transgenic mouse model of Parkinson's disease. Brain 133:2032-2044.

Giasson BI, Duda JE, Quinn SM, Zhang B, Trojanowski JQ, Lee VM (2002) Neuronal alpha-synucleinopathy with severe movement disorder in mice expressing A53T human alpha-synuclein. Neuron 34:521-533.

Goldmann Gross R, Siderowf A, Hurtig HI (2008) Cognitive impairment in Parkinson's disease and dementia with Lewy bodies: a spectrum of disease. Neurosignals 16:24-34.

Gómez-Tortosa E, Newell K, Irizarry MC, Sanders JL, Hyman BT (2000) Alpha-synuclein immunoreactivity in dementia with Lewy bodies: morphological staging and comparison with ubiquitin immunostaining. Acta Neuropathol 99:352-357.

Hanson JC, Lippa CF (2009) Lewy body dementia. Int Rev Neurobiol $84: 215-228$

Ikeuchi T, Kakita A, Shiga A, Kasuga K, Kaneko H, Tan CF, Idezuka J, Wakabayashi K, Onodera O, Iwatsubo T, Nishizawa M, Takahashi H, Ishikawa A (2008) Patients homozygous and heterozygous for SNCA duplication in a family with parkinsonism and dementia. Arch Neurol 65:514-519.

Jankowsky JL, Slunt HH, Gonzales V, Savonenko AV, Wen JC, Jenkins NA, Copeland NG, Younkin LH, Lester HA, Younkin SG, Borchelt DR (2005) Persistent amyloidosis following suppression of Abeta production in a transgenic model of Alzheimer disease. PLoS Med 2:e355.

Jellinger KA (2004) Lewy body-related alpha-synucleinopathy in the aged human brain. J Neural Transm 111:1219-1235.

Kahle PJ, Neumann M, Ozmen L, Muller V, Jacobsen H, Spooren W, Fuss B, Mallon B, Macklin WB, Fujiwara H, Hasegawa M, Iwatsubo T, Kretzschmar HA, Haass C (2002) Hyperphosphorylation and insolubility of alpha-synuclein in transgenic mouse oligodendrocytes. EMBO Rep 3:583-588.

Kim JJ, Fanselow MS (1992) Modality-specific retrograde-amnesia of fear. Science 256:675-677.

Kotzbauer PT, Giasson BI, Kravitz AV, Golbe LI, Mark MH, Trojanowski JQ, Lee VM (2004) Fibrillization of alpha-synuclein and tau in familial Parkinson's disease caused by the A53T alpha-synuclein mutation. Exp Neurol 187:279-288.

Kramer ML, Schulz-Schaeffer WJ (2007) Presynaptic alpha-synuclein ag- gregates, not Lewy bodies, cause neurodegeneration in dementia with Lewy bodies. J Neurosci 27:1405-1410.

Kuwahara T, Koyama A, Koyama S, Yoshina S, Ren CH, Kato T, Mitani S, Iwatsubo T (2008) A systematic RNAi screen reveals involvement of endocytic pathway in neuronal dysfunction in alpha-synuclein transgenic $C$. elegans. Hum Mol Genet 17:2997-3009.

Kuzuhara S, Mori H, Izumiyama N, Yoshimura M, Ihara Y (1988) Lewy bodies are ubiquitinated-a light and electron-microscopic immunocytochemical study. Acta Neuropathol 75:345-353.

Larsen KE, Schmitz Y, Troyer MD, Mosharov E, Dietrich P, Quazi AZ, Savalle M, Nemani V, Chaudhry FA, Edwards RH, Stefanis L, Sulzer D (2006) $\alpha$-Synuclein overexpression in PC12 and chromaffin cells impairs catecholamine release by interfering with a late step in exocytosis. J Neurosci 26:11915-11922.

Lennox G, Lowe J, Morrell K, Landon M, Mayer RJ (1989) Anti-ubiquitin immunocytochemistry is more sensitive than conventional techniques in the detection of diffuse Lewy body disease. J Neurol Neurosurg Psychiatry 52:67-71.

Lim Y, Kehm VM, Li C, Trojanowski JQ, Lee VM (2010) Forebrain overexpression of alpha-synuclein leads to early postnatal hippocampal neuron loss and synaptic disruption. Exp Neurol 221:86-97.

Love S, Nicoll JA (1992) Comparison of modified Bielschowsky silver impregnation and antiubiquitin immunostaining of cortical and nigral Lewy bodies. Neuropathol Appl Neurobiol 18:585-592.

Mayford M, Bach ME, Huang YY, Wang L, Hawkins RD, Kandel ER (1996) Control of memory formation through regulated expression of a CaMKII transgene. Science 274:1678-1683.

McKeith IG, Dickson DW, Lowe J, Emre M, O’Brien JT, Feldman H, Cummings J, Duda JE, Lippa C, Perry EK, Aarsland D, Arai H, Ballard CG, Boeve B, Burn DJ, Costa D, Del Ser T, Dubois B, Galasko D, Gauthier S, et al. (2005) Diagnosis and management of dementia with Lewy bodiesthird report of the DLB Consortium. Neurology 65:1863-1872.

Mikolaenko I, Pletnikova O, Kawas CH, O'Brien R, Resnick SM, Crain B, Troncoso JC (2005) Alpha-synuclein lesions in normal aging, Parkinson disease, and Alzheimer disease: evidence from the Baltimore Longitudinal Study of Aging (BLSA). J Neuropathol Exp Neurol 64:156-162.

Nemani VM, Lu W, Berge V, Nakamura K, Onoa B, Lee MK, Chaudhry FA, Nicoll RA, Edwards RH (2010) Increased expression of alpha-synuclein reduces neurotransmitter release by inhibiting synaptic vesicle reclustering after endocytosis. Neuron 65:66-79.

Nuber S, Petrasch-Parwez E, Winner B, Winkler J, von Hörsten S, Schmidt T, Boy J, Kuhn M, Nguyen HP, Teismann P, Schulz JB, Neumann M, Pichler BJ, Reischl G, Holzmann C, Schmitt I, Bornemann A, Kuhn W, Zimmermann F, Servadio A, et al. (2008) Neurodegeneration and motor dysfunction in a conditional model of Parkinson's disease. J Neurosci 28:2471-2484.

Ohara K, Takauchi S, Kokai M, Morimura Y, Nakajima T, Morita Y (1999) Familial dementia with Lewy bodies (DLB). Clin Neuropathol $18: 232-239$

Paleologou KE, Schmid AW, Rospigliosi CC, Kim HY, Lamberto GR, Fredenburg RA, Lansbury PT Jr, Fernandez CO, Eliezer D, Zweckstetter M, Lashuel HA (2008) Phosphorylation at Ser-129 but not the phosphomimics S129E/D inhibits the fibrillation of alpha-synuclein. J Biol Chem 283:16895-16905.

Parkkinen L, Soininen H, Alafuzoff I (2003) Regional distribution of alphasynuclein pathology in unimpaired aging and Alzheimer disease. J Neuropath Exp Neurol 62:363-367.

Paxinos G, Franklin KBJ (2011) The mouse brain in stereotaxic coordinates. San Diego: Academic.

Sampathu DM, Giasson BI, Pawlyk AC, Trojanowski JQ, Lee VM (2003) Ubiquitination of alpha-synuclein is not required for formation of pathological inclusions in alpha-synucleinopathies. Am J Pathol 163:91-100.

Santacruz K, Lewis J, Spires T, Paulson J, Kotilinek L, Ingelsson M, Guimaraes A, DeTure M, Ramsden M, McGowan E, Forster C, Yue M, Orne J, Janus C, Mariash A, Kuskowski M, Hyman B, Hutton M, Ashe KH (2005) Tau suppression in a neurodegenerative mouse model improves memory function. Science 309:476-481.

Satake W, Nakabayashi Y, Mizuta I, Hirota Y, Ito C, Kubo M, Kawaguchi T, Tsunoda T, Watanabe M, Takeda A, Tomiyama H, Nakashima K, Hasegawa K, Obata F, Yoshikawa T, Kawakami H, Sakoda S, Yamamoto M, Hattori N, Murata M, et al. (2009) Genome-wide association study 
identifies common variants at four loci as genetic risk factors for Parkinson's disease. Nat Genet 41:1303-1307.

Scott DA, Tabarean I, Tang Y, Cartier A, Masliah E, Roy S (2010) A pathologic cascade leading to synaptic dysfunction in alpha-synuclein-induced neurodegeneration. J Neurosci 30:8083-8095.

Seidel K, Schöls L, Nuber S, Petrasch-Parwez E, Gierga K, Wszolek Z, Dickson D, Gai WP, Bornemann A, Riess O, Rami A, Den Dunnen WF, Deller T, Rüb U, Krüger R (2010) First appraisal of brain pathology owing to A30P mutant alpha-synuclein. Ann Neurol 67:684-689.

Simón-Sánchez J, Schulte C, Bras JM, Sharma M, Gibbs JR, Berg D, PaisanRuiz C, Lichtner P, Scholz SW, Hernandez DG, Krüger R, Federoff M, Klein C, Goate A, Perlmutter J, Bonin M, Nalls MA, Illig T, Gieger C, Houlden $\mathrm{H}$, et al. (2009) Genome-wide association study reveals genetic risk underlying Parkinson's disease. Nat Genet 41:1308-1312.

Soper JH, Roy S, Stieber A, Lee E, Wilson RB, Trojanowski JQ, Burd CG, Lee VM (2008) $\alpha$-Synuclein-induced aggregation of cytoplasmic vesicles in Saccharomyces cerevisiae. Mol Biol Cell 19:1093-1103.

Spillantini MG, Schmidt ML, Lee VM, Trojanowski JQ, Jakes R, Goedert M (1997) Alpha-synuclein in Lewy bodies. Nature 388:839-840.

Spira PJ, Sharpe DM, Halliday G, Cavanagh J, Nicholson GA (2001) Clinical and pathological features of a parkinsonian syndrome in a family with an Ala53Thr alpha-synuclein mutation. Ann Neurol 49:313-319.
Thayanidhi N, Helm JR, Nycz DC, Bentley M, Liang Y, Hay JC (2010) $\alpha$-Synuclein delays endoplasmic reticulum (ER)-to-Golgi transport in mammalian cells by antagonizing ER/Golgi SNAREs. Mol Biol Cell 21:1850-1863.

Tremblay P, Meiner Z, Galou M, Heinrich C, Petromilli C, Lisse T, Cayetano J, Torchia M, Mobley W, Bujard H, DeArmond SJ, Prusiner SB (1998) Doxycycline control of prion protein transgene expression modulates prion disease in mice. Proc Natl Acad Sci U S A 95:12580-12585.

van Ham TJ, Thijssen KL, Breitling R, Hofstra RM, Plasterk RH, Nollen EA (2008) C. elegans model identifies genetic modifiers of alpha-synuclein inclusion formation during aging. PLoS Genet 4:e100027.

Waxman EA, Giasson BI (2008) Specificity and regulation of casein kinasemediated phosphorylation of alpha-synuclein. J Neuropathol Exp Neurol 67:402-416.

Zaccai J, McCracken C, Brayne C (2005) A systematic review of prevalence and incidence studies of dementia with Lewy bodies. Age Ageing 34: 561-566.

Zhang B, Veasey SC, Wood MA, Leng LZ, Kaminski C, Leight S, Abel T, Lee VM, Trojanowski JQ (2005) Impaired rapid eye movement sleep in the Tg2576 APP murine model of Alzheimer's disease with injury to pedunculopontine cholinergic neurons. Am J Pathol 167:1361-1369. 